$\xi_{3}=-1$

\title{
Evaluation of geotechnical properties of gully erosion materials in ORLU and its environs, IMO state, Nigeria
}

\author{
Iheme, O.K ${ }^{1 *}$, Okoye V.U. ${ }^{2}$, Chinwuko A.I. ${ }^{3}$, Usman A.O. ${ }^{4}$, Ejeke C.F. ${ }^{4}$, Osele, C.E ${ }^{4}$ \\ ${ }^{1}$ Department of Geology and Mineral Sciences, University of Ilorin, Kwara State, Nigeria \\ ${ }^{2}$ Department of Urban and Regional Planning, Abia State Polytechnic, Abia State, Nigeria \\ ${ }^{3}$ Department of Geology, Federal University Gusau, Zamfara State, Nigeria \\ ${ }^{4}$ Department of Geology, Nnamdi Azikwe University, Awka, Nigeria \\ *Corresponding author E-mail: ihemeko@yahoo.com
}

\begin{abstract}
The evaluation of geotechnical properties of rock materials is used to ascertain the environmental factor that necessitated gully erosion in Orlu and its environs, Imo State, Nigeria. The study is aimed at geotechnically defining the characteristics, causes and formation of the gully erosion with particular emphasis on the current land degradation in the study area. Data used in the study were derived from field measurements, and laboratory analysis. Gully variables such as length, depth and widths were also determined. The result of the geological mapping revealed that there are three geologic formations encountered in the study area namely; Ameki, Ogwashi Asaba, and Benin Formations. The result of the field studies shows that $27 \%$ of the gullies observed occur in Ameki Formation while no gully was discovered in Ogwashi Asaba formation. The grain size distribution curves interpretation revealed that $80 \%$ (by weight) of the soils are medium to coarse grained sand and fine gravels, while the remaining $18 \%$ and $2 \%$ are for fine grained sand and coarse grained silt. The Atterberg Limit Test interpretation shows that the plasticity index of the formations ranges from $24.83 \%$ to $48.42 \%$. Based on the results of the geotechnical properties of rock materials in the study area, the factors responsible for gullies occurrence in the study area were identified as topography, rainfall, geology, and anthropogenic factors. The devastating effects of gully erosion in the study area were observed to include loss of about $22 \mathrm{~km} 2$ of arable lands; 2 major and 6 minor road failures; loss of many houses and other infrastructures; pollution of surface and underground water. Finally, it is recommended that the appropriate authorities, individuals and all stakeholders in the environmental protection agency should develop ideas in environment watch towards gully erosion control.
\end{abstract}

Keywords: Gully Erosion; Gully Variables; Grain Size; Plasticity and ORLU.

\section{Introduction}

Geologic environment of Orlu and environs has undergone destruction due to natural phenomena and man-made activities. Most common natural disasters of different magnitudes affecting the area include landslides and gully erosion (Okagbue and Uma 1987). The formation of gullies has become one of the greatest environmental disasters facing many towns and villages in Southeastern Nigeria (Adekalu et al., 2007). This region is fast becoming hazardous for human habitation with resultant problems of destruction of roads, economic trees, houses, and loss of arable land. Hundreds of people are being directly affected every year and needs to be re-located. Large areas of agricultural lands are becoming unsuitable for cultivation as erosion destroys farmlands and lowers agricultural productivity (Egboka et al., 1990). Therefore, the objective of this study is to investigate the occurrence, source and possible solutions to the gully erosion in Orlu and environs.

\section{Location and accessibility}

The area of study comprises Orlu town, Amucha, Nkwerre, Amigbo, Umuaka, Nduche and many others which are all located in Imo State, South-eastern, Nigeria (Fig. 1).
It lies between latitudes $5^{\mathrm{o}} 39^{\mathrm{I}} \mathrm{N}-5^{\mathrm{o}} 50^{\mathrm{I}} \mathrm{N}$ and longitudes $7^{\mathrm{o}} 09^{\mathrm{I}} \mathrm{E}$ $8^{\mathrm{o}} 20^{\mathrm{I}} \mathrm{E}$. It is bounded on the North by Urualla, on the East by Okigwe towns, on the South by Ogwa, and on the West by Mgbidi, and covers about $268 \mathrm{~km}^{2}$ in area. The study area is accessible from numerous neighbouring towns and villages through state and local government roads (Fig 1). Earth roads and footpaths equally abound, both of which facilitated access to gullies located away from the major roads.

Rainy and dry seasons are the two main climatic conditions existing in the study area. The dry season runs through the months of November to March while the rainy season begins in April and ends in October but may also extend to November.

\section{Methods of investigation}

Data used in this study were derived from field measurements. Satellite imageries were used to prepare the maps and soil samples were subjected to laboratory analysis. Profiles were taken at $100 \mathrm{~m}$ sample points intervals to delineate gully morphological variables, while soil samples were taking along the gully wall layers (top, middle and bottom) and a representative sample picked from this composite sample in order to analyse the geotechnical properties of the soil. A 30m tape, cone penetrometer and soil sampler were used. Data collected were analysed using a descriptive statistic. Sieve analysis for grain distribution, and Atterberg limits tests 
were conducted on the samples. The grain size distribution analysis was carried out using mechanical shaker,

A detailed geologic field mapping exercise was conducted and the result used to prepare the detailed gully site and geologic map of the study area (Fig. 2). Gully characteristics like length, breadth, depth and orientation were taken. Soil samples were taken from the gullies and used to determine the geotechnical properties of the samples. Parameters determined include plastic limits, liquid limits and plasticity index.

\subsection{Geology and hydrogeology of the area}

The study area falls between two of the Nigeria sedimentary basins namely; Niger Delta Basin and Anambra Basin (Table 2). Cenozoic Niger Delta complex was developed as a regressive offlap sequences. Three major lithostratigraphic units recognized in the Niger Delta are the Akata, Agbada and Benin Formations (from the oldest to the youngest).

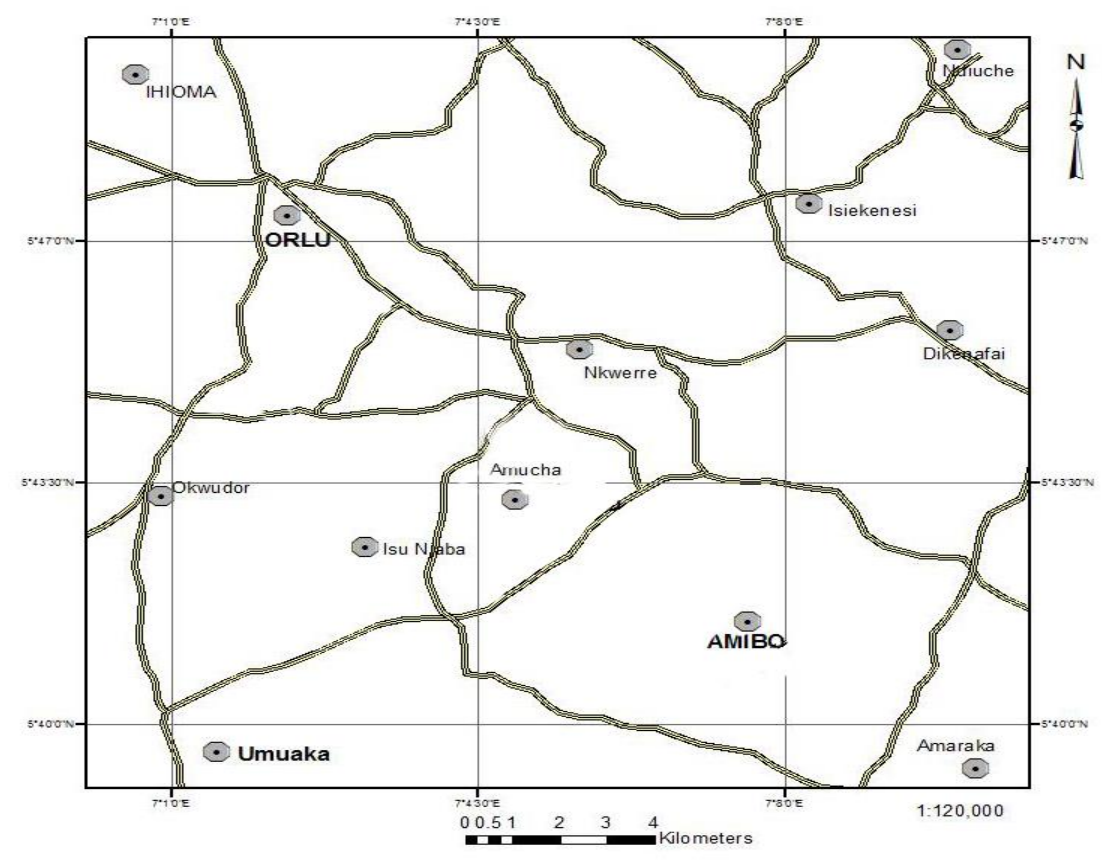

Key

- Towns $=$ Roads

Fig. 1: Accessibility Map of the Study Area.
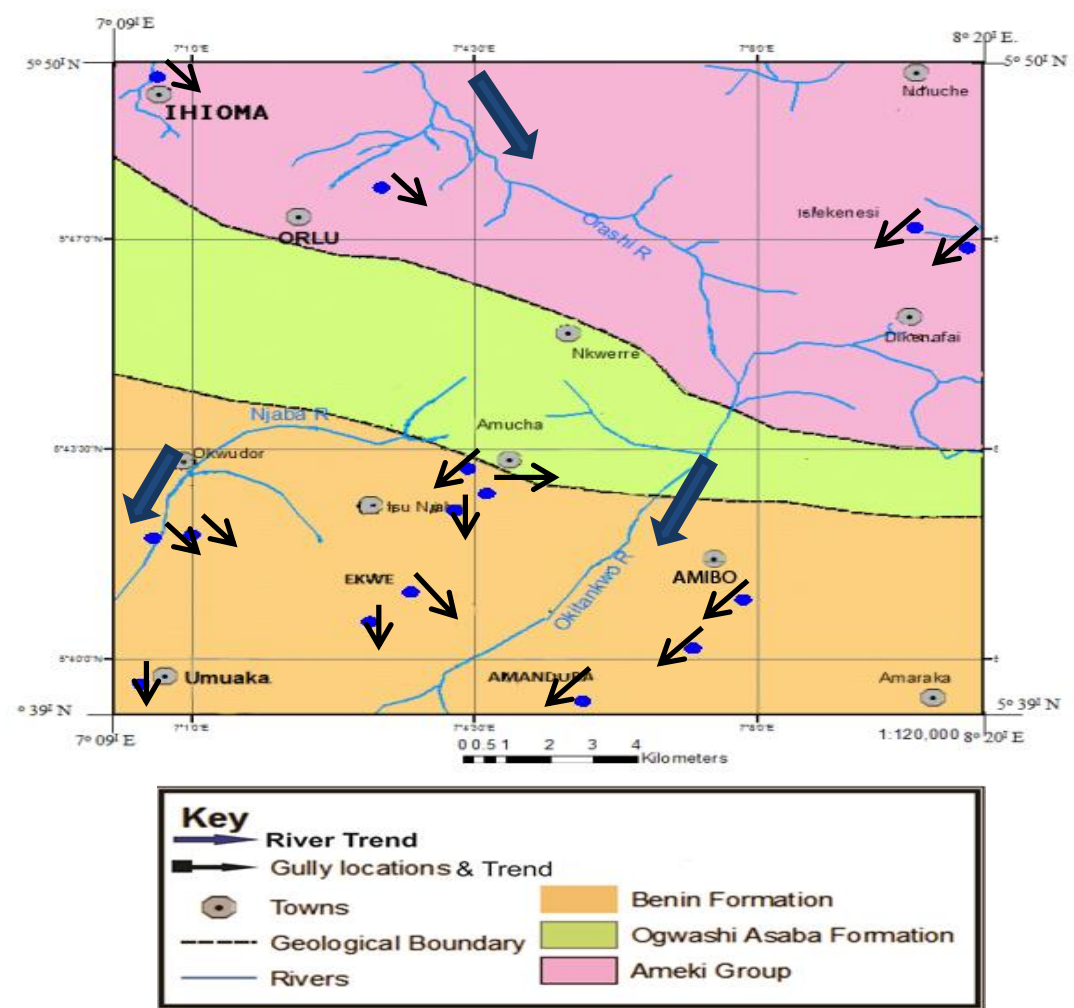

Fig. 2: Geologic Map of the Study Area Showing Major Gully Locations and River Trends 
The Akata Formation is composed of continuous shale and about $10 \%$ sandstone. Its age ranges from Eocene to Recent. The Agbada Formation conformably overlies the Akata Formation in the subsurface. It is a parallic sequence of alternating shale and sandstone with a variable age ranging from Eocene in the north to Pliocene/Pleistocene in the south and Recent in the Delta surface. The Agbada Formation is thickest at the center of the Delta with a thickness of up to $457.2 \mathrm{~m}$. The continental Miocene-Recent Benin Formation conformably overlies the Agbada Formation. It is composed of loose fresh water bearing sand with occasional lignite and clay and going up to 2,286 m deep with no over pressures. It is made of more than $90 \%$ sands and about $10 \%$ shale/clays. (Burke, 1996).

On the other hand, the Anambra Basin is the most prominent basin formed during the Abakaliki tectonic episode (Igbokwe, et al. 2008). The Anambra Basin is dominantly filled with clastic sediments constituting several distinct lithostratigraphic units ranging from Upper Campanian to Recent in age. The lithostratigraphic units have a thickness of up to $2500 \mathrm{~m}$ (Reyment, 1965), and includes Nkporo Shale, Mamu Formation, Ajali Sandstone, Nsukka Formation, Imo Shale, Ameki Formation, Nanka Sands. The area is underlain by Ameki Formation, Ogwashi-Asaba Formation and Benin Formation (Fig.2).
The climate and the hydro-geologic conditions of the region control the surface and groundwater in the area. The surface water is a major factor in the formation of gullies in the study area as the gullies are closely linked to the drainage (Egboka 1983) (Fig. 3). The study area is drained by two major river systems: Njaba River in the south west and Orashi River system extending from the north to the south of the study area.

\subsection{Assessment of gully sites}

Gully geometry, coordinates, location, dimensions, and inferred causes were determined and in the study area. The results are tabulated in table 1

\subsection{Distribution of gullies}

The gully erosion distribution in the formations of the study area is illustrated below (Fig. 5). No gully was discovered in Ogwashi Asaba Formation.

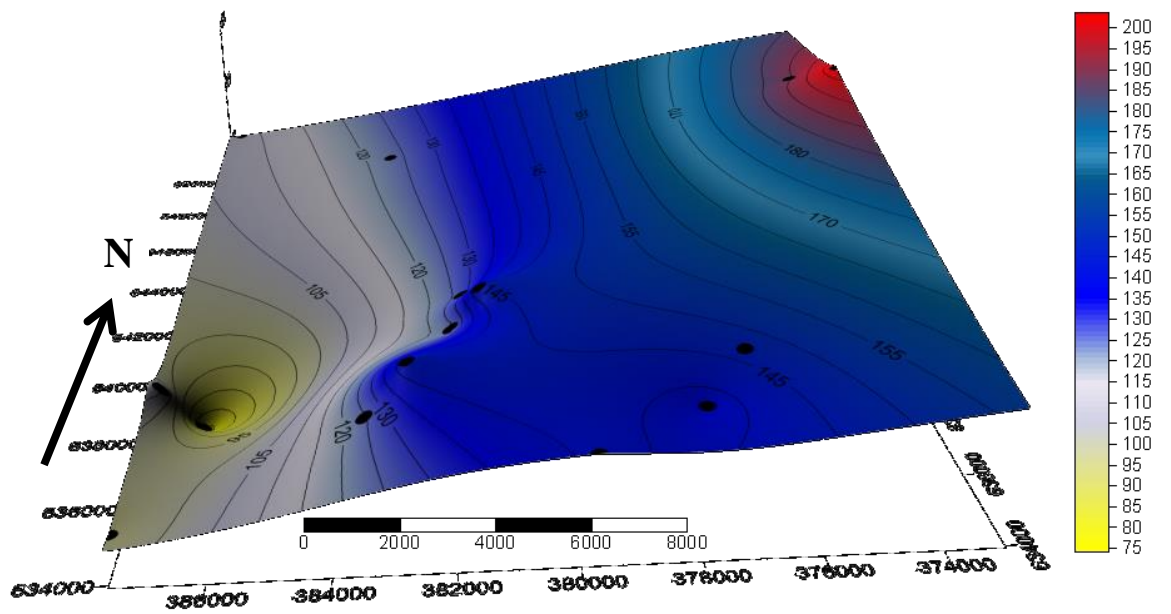

Fig. 3: Current Topographic Outlook of the Study Area Showing Locations of the Gully Sites Plotted with GPS Readings.

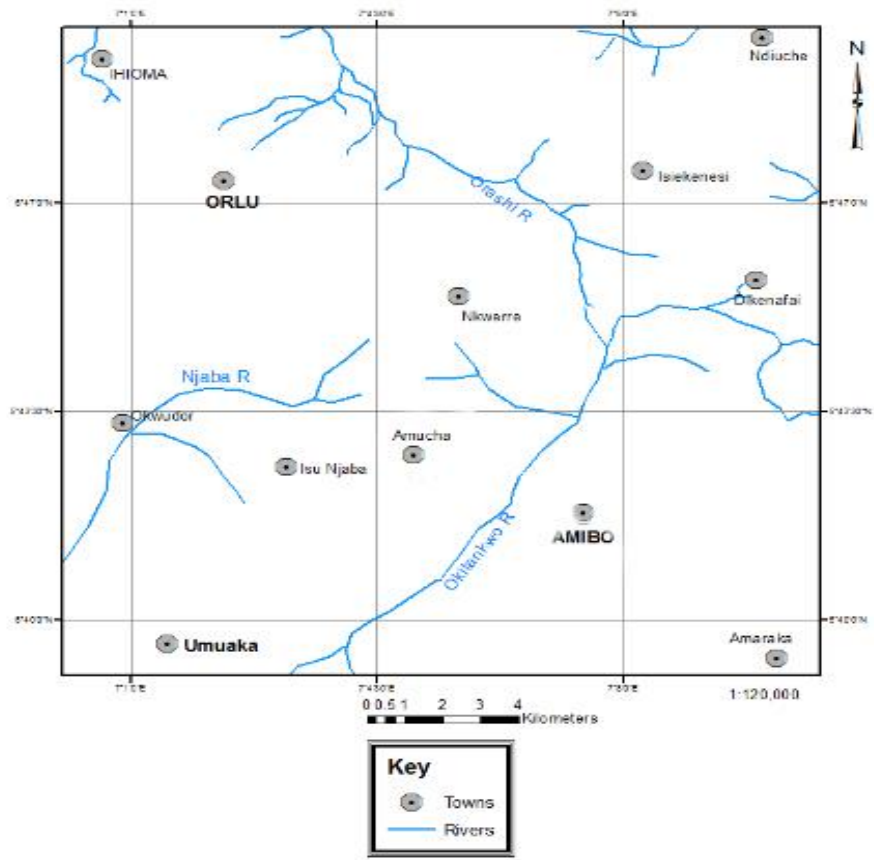

Fig. 4: Drainage Map of the Study Area. 
Table 1: Inventory of Gully Sites at the Study Area

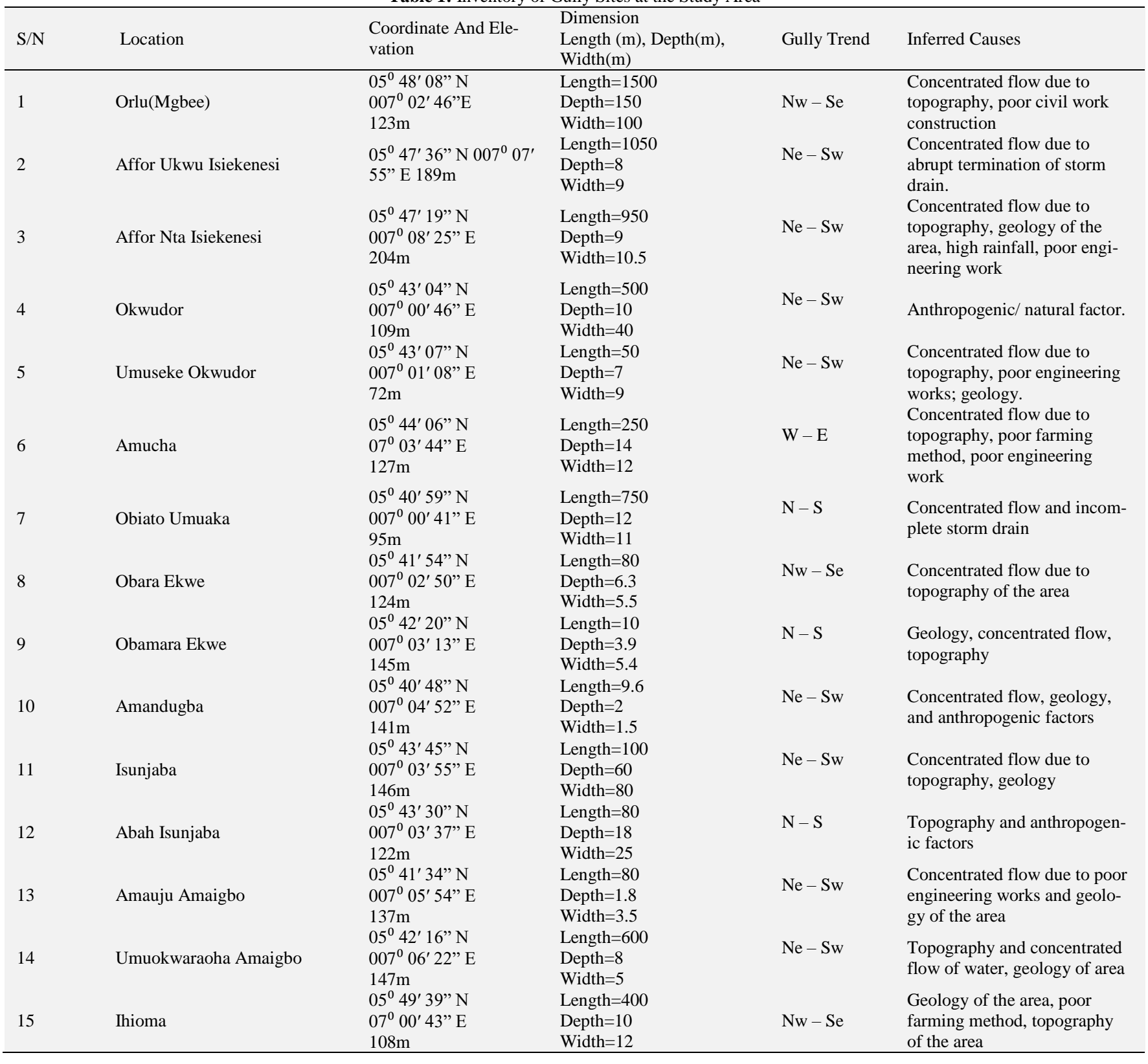

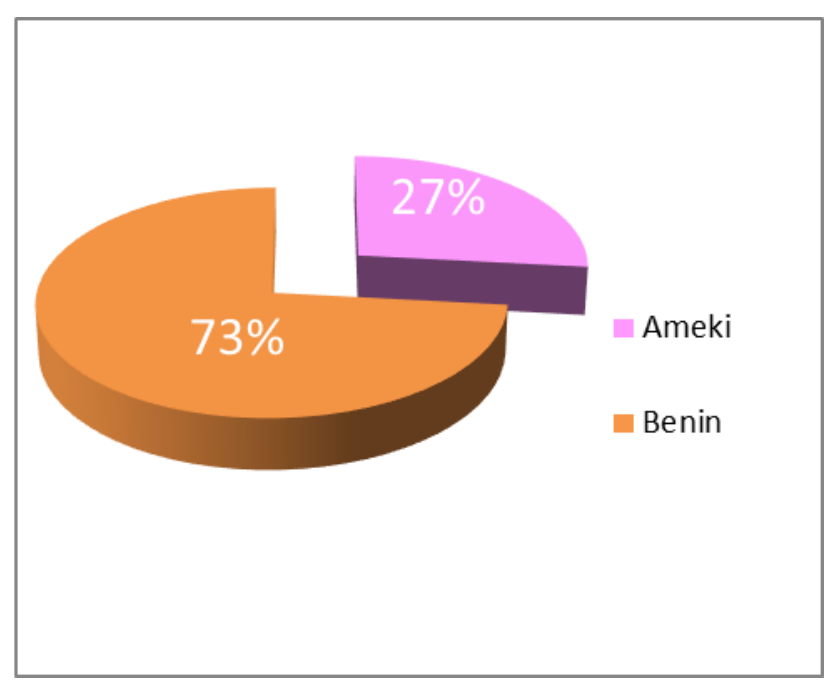

Fig. 5: Distribution of Gullies in the Formations in the Study Area.

Results and Interpretation (Geotechnical Analysis Results) 
Table 2: Grain Size Parameters for Soil Samples

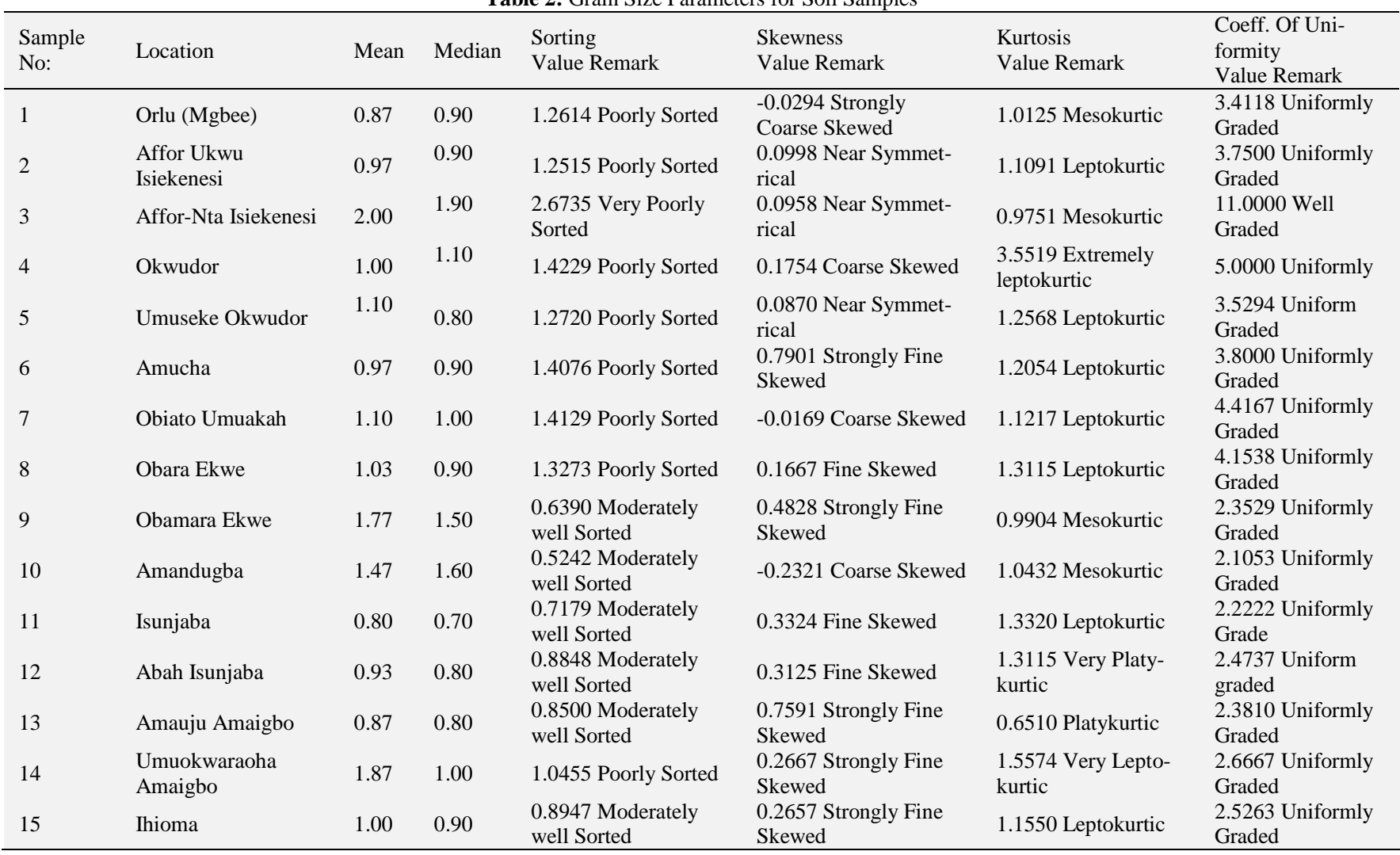

Table 3: Atterberg Limit Test within the Study Area

\begin{tabular}{llll}
\hline Sample No & Location Name & Liquid Limit (\%) & Plastic Limit (\%) \\
\hline 1 & Orlu (Mgbee) & 60 & 22.48 \\
2 & Afor-Ukwu, Isiekenesi & 54.2 & 20.36 \\
3 & Afor-Nta, Isiekenesi & 61 & 20.75 \\
4 & Okwudor & Non Plastic & Non Plastic \\
5 & Umuseke, Okwudor & Non Plastic & Non Plastic \\
6 & Amucha & 64.4 & 18.65 \\
7 & Obiato-Umuakah & Non Plastic & Non Plastic \\
8 & Obara-Ekwe & Non Plastic & Non Plastic \\
9 & Obamara-Ekwe & Non Plastic & Non Plastic \\
10 & Amandugba & Non Plastic & Non Plastic \\
11 & Isunjaba & Non Plastic & Non Plastic \\
12 & Abah, Isunjaba & Non Plastic & Non Plastic \\
13 & Amauju, Amaibo & 44.75 & 19.92 \\
14 & Umuokwaraoha, Amaigbo & 62.5 & 19.6 \\
15 & Ihioma & 65 & 16.08 \\
\hline
\end{tabular}

Table 4: Effective Size (D10), (D60) and Phi (Ф) Values for Soil Samples

\begin{tabular}{|c|c|c|c|c|c|c|c|c|c|c|}
\hline Soil Sample No: & Location & $\begin{array}{l}\text { Effective Size (D10) } \\
(\mathrm{mm})\end{array}$ & $\begin{array}{l}\text { D60 Size } \\
(\mathrm{mm})\end{array}$ & $\varphi 5$ & $\varphi 16$ & $\varphi 25$ & $\varphi 50$ & $\varphi 75$ & $\varphi 84$ & $\varphi 95$ \\
\hline 1 & Orlu(Mgbee) & 0.17 & 0.58 & -1.20 & -0.40 & 0.10 & 0.90 & 1.80 & 2.10 & 3.00 \\
\hline 2 & $\begin{array}{l}\text { Affor Ukwu } \\
\text { Isiekenesi }\end{array}$ & 0.16 & 0.60 & -1.00 & -0.20 & 0.20 & 0.90 & 1.80 & 2.20 & 3.30 \\
\hline 3 & $\begin{array}{l}\text { Afor Nta } \\
\text { Isiekenesi }\end{array}$ & 0.03 & 0.33 & -1.10 & -0.40 & 0.50 & 1.90 & 3.40 & 4.50 & 5.8 \\
\hline 4 & Okwudor & 0.10 & 0.55 & -1.00 & -0.10 & 1.30 & 1.00 & 1.90 & 2.40 & 4.20 \\
\hline 5 & Umuseke Okwudor & 0.17 & 0.60 & -1.20 & -0.30 & 0.10 & 0.80 & 1.60 & 2.00 & 3.40 \\
\hline 7 & Obiato Umuaka & 0.12 & 0.53 & -1.20 & -0.10 & 0.10 & 1.00 & 2.00 & 2.40 & 4.00 \\
\hline 8 & Obara Ekwe & 0.13 & 0.54 & -1.10 & -0.10 & 0.30 & 0.90 & 1.80 & 2.30 & 3.70 \\
\hline 9 & Obamar Ekwe & 0.17 & 0.40 & 0.00 & 1.50 & 0.80 & 1.50 & 2.00 & 2.30 & 2.90 \\
\hline 10 & Amandugba & 0.19 & 0.40 & -0.10 & 0.60 & 1.00 & 1.60 & 2.10 & 2.20 & 2.70 \\
\hline 11 & Isunjaba & 0.18 & 0.40 & -0.10 & 0.20 & 0.40 & 0.70 & 1.20 & 1.50 & 2.50 \\
\hline 12 & Abah Isunjaba & 0.19 & 0.47 & -0.20 & 0.20 & 0.40 & 0.80 & 1.40 & 1.80 & 3.00 \\
\hline 13 & Amauju Amaigbo & 0.21 & 0.50 & -0.10 & 0.20 & 0.40 & 0.80 & 1.30 & 1.60 & 2.60 \\
\hline 14 & Umuokwaraoha Amaigbo & 0.15 & 0.40 & -0.20 & 0.20 & 0.40 & 1.00 & 1.80 & 2.20 & 3.40 \\
\hline
\end{tabular}




\section{Discussion of results}

The lengths of the gullies within the study area range from $9.6 \mathrm{~m}$ at Amandugba, to $1500 \mathrm{~m}$ at Orlu-Mgbee. Their width ranges from $1.5 \mathrm{~m}$ at Amandugba to $100 \mathrm{~m}$ at Orlu-Mgbee and their depths from $2 \mathrm{~m}$ at Amandugba to $60 \mathrm{~m}$ at Isunjaba. The gullies were found to have predominately $\mathrm{V}$-shaped structures indicating that they are active, and the major trends of the gully are NW-SE, NE-SW and $\mathrm{N}-\mathrm{S}$ (Table 1). The coordinates and dimension of the gullies as show in Table 1 help in predicting gully heads.

Results from the grain size distribution curves indicate that about $80 \%$ ( by weight) of the soils are medium to coarse grained sand and fine gravels which are easily eroded by runoff water, while the remaining $18 \%$ and $2 \%$ are fine grained sand and coarse grained silt (Fig. 6) which are easily erodible soil materials. The various effective grain sizes and Phi values for soil samples collected and analysed indicates that the samples range from very poorly sorted (at Afor-nta, Isiekenesi) to moderately sorted (at Ihioma). The analysis also shows that the samples ranges from strongly fine skewed to strongly coarse skewed. In addition, the result shows that the kurtosis of the samples ranges from very platykurtic (very flat) to extreme leptokurtic (very peak) and the coefficient of uniformity obtained from the samples indicates that the soil samples are uniformly graded within the study area except Afor-nta Isiekenesi that has well graded soil (Table 4).

Based on the grain size analysis of the soil samples, removal and transport of the soil grains by runoff water is easier. Smaller particles are easily carried away by water since the transporting medium requires relatively small amount of energy. This is why erodibility potential of the soil units is high within the study area.

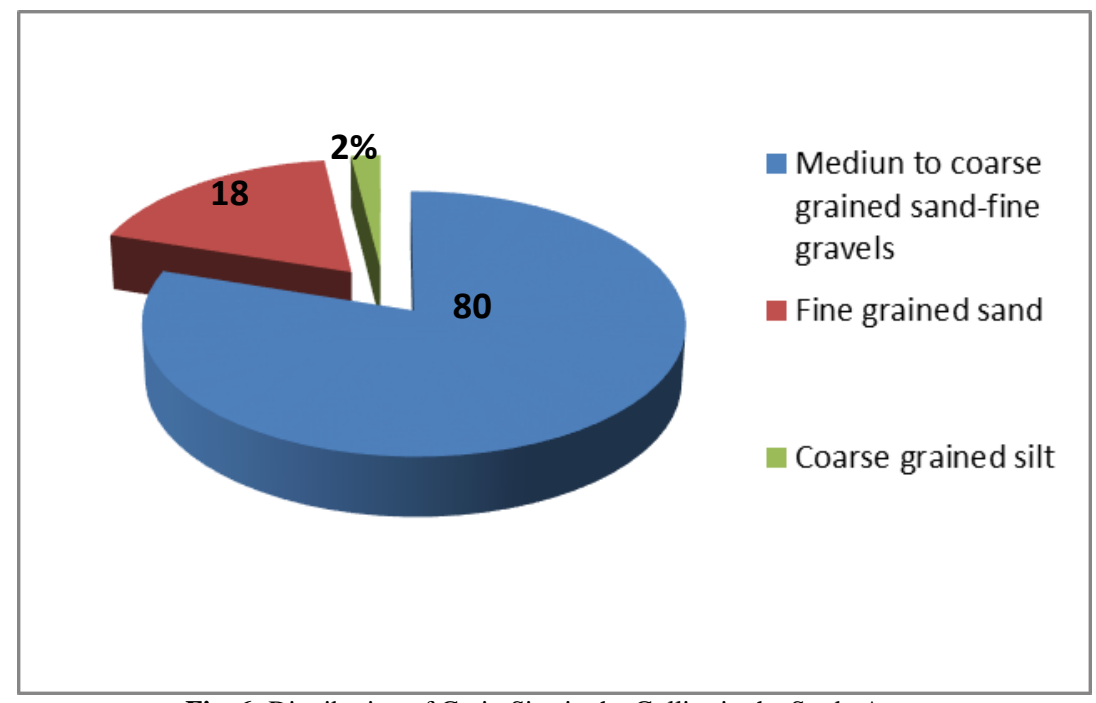

Fig. 6: Distribution of Grain Size in the Gullies in the Study Area.

The results from the Atterberg Limit Tests (Table 5) indicate the existence of two classes of soil materials namely - plastic material and non-plastic material. About 53\% of the samples collected are non-plastic while $47 \%$ are plastic. The areas that have plastic materials are Orlu-Mgbee, Afor-Ukwu Isiekenesi, Afor-Nta Isekenesi, Amucha, Amauju-Amaibo, Umuokwaraoha-Amaigbo and Ihioma. The moderate clay content of the soil materials within some part of the study area was found to reduce the devastation caused by gullies in the area. The liquid limit ranges from $44.75 \%$ to $65 \%$ while the plastic limit ranges from $16.08 \%$ to $22.48 \%$ and plasticity index ranges from $48.92 \%$ to $24.83 \%$. The areas without plastic soil material are highly affected by the gullies since low plasticity of the soil units indicates low cohesive force between grains. They include Okwudor, Umuseke-Okwudor, ObiatoUmuaka, Obara-Ekwe, Obamara-Ekwe, Amandugba, Isunjaba, and Abah-Isunjaba.

\section{Conclusion and recommendations}

\section{1. Conclusion}

The conditions that favour gully erosion in the Ameki and the Benin Formations are complete within the study area. These include high rainfall, steep slope, friable substratum and intense human activities. Field studies show that the environmental hazard posed by gullying has continued to defy control measure put in place to checkmate it, as a result of the peculiar geological, hydrogeological, geotechnical, climate and anthropogenic factors at play in the area. It is calculated from the gully dimensions that $22 \mathrm{~km}^{2}$ out of the $268 \mathrm{~km}^{2}$ total land mass in Orlu and its environs has been lost to gully erosion. Since gullying is progressive, the dimension and features of individual gullies, as well as the numbers of gullies in Orlu and its environs will continue to change. In addition, the study has shown that the soils in this area have a high percentage of sand and high sand to clay ratio. This type of soil belongs to 'irrigable' class of the Modified US Bureau of Reclamation Land Suitability Class specifications (Usman et al., 2014), are highly erodible.

The gullies in the study area are genetically related to the three major drainage systems whose sources are from the northern upland (Awka - Orlu cuesta) and the east central plateau, namely: Orasi River system, Njaba River systems and Okitankwo River systems. It was observed that among the three river systems in the study area, the most active gullies are concentrated in the Orashi Njaba system (Fig 3) with over $80 \%$ of gullies in the study area. There is the consensus among Geoscientist and other Earth scientists working on the gullies in South Eastern Nigeria that the control of the disaster should be scientifically and systematically implemented rather than the common and general practice of channelization and embankment construction (Ezechi and Okagbue 1989, Egboka and Okpoko,1984).

\subsection{Recommendations}

It is recommended that the appropriate authorities, individuals and all stakeholders in environmental protection shall constitute the major factors in environment watch towards gully erosion control-

- Agricultural practices like bush burning which is prevalent in Umuakah, Njaba, should be discouraged.

- Incipient control measures like use of sandbags, fence filter mechanism, and use of catch-pits should be encouraged. 
This control measure is already in use in places like Isiekenesi.

- Slope stabilization by reducing the slope angle during road construction should be encouraged.

- Afforestation should be practiced to provide vegetative cover that will reduce the impact of raindrop energy at Amandugba.

- Multi-channelling should be a popular practice to help reduce the flow velocity of runoff in Orlu Mgbee.

- Proper assessment and treatment of water in the study area before human consumption should always be undertaken to avoid diseases associated with water contamination by runoff.

- Monitoring of the unaffected areas to ensure the practice of prevention and compliance with anti-erosion statutes should be enforced by the relevant authorities.

\section{References}

[1] Adepetu, J.A., Nabhan, H. and Osinubi, A., (2000). Simple soil, water and plant testing techniques for soil resource management, Proceedings of a training course held in Ibadan, Nigeria, 16-27 September 1996, IITA/FAO, Rome, p.166.

[2] Adekalu, K. O., Olorunfemi, I. A., Osunbitan, J. A., (2007). Grass mulching effect on infiltration, surface runoff and soil loss of three agricultural soils in Nigeria. Bioresour. Technol., 98(4): pp.912-917. http://dx.doi.org/10.1016/j.biortech.2006.02.044.

[3] Burke, K.C., (1996). The African Plate. South African Journal of Geology 99, pp.341-409.

[4] Egboka, B.C.E., (1983). Water resources of Nsukka area and the environs. Nig. J. Min. Geol. 20 (1 and 2), pp.1 - 16.

[5] Egboka, B. C. E., Nwakwor, G. I., and Orajiaka, I. P., (1990). Implications of palaeo and neotectonics in gully erosion-prone areas of south-eastern Nigeria. Natural Hazards, 3: pp.219-220-231.

[6] Egboka, B.C.E. and Okpoko, E.I., (1984). Gully erosion in the Agulu-Nanka region of Anambra State, Nigeria. Proceedings of the Harare symposium. IAHS Publication, 144, pp.335-347.

[7] Ezechi, J.I. and Okagbue, C.O., (1989). A genetic classification of gullies in eastern Nigeria and its implications on control measures. Journal of African Earth Sciences, 9, pp. 711-718. http://dx.doi.org/10.1016/0899-5362(89)90056-0.

[8] George N, Akpan A, Obot I, Akpanetuk N (2008). Geoelectrical investigation of erosion and flooding using the lithologic compositions of erosion and flood-stricken road in ukanafun local government area, Akwa Ibom State, Southern Nigeria. Disaster Adv., 1(4): pp 46-51.

[9] Godwin I. Nwankwor, Ubong P. Udoka1., Boniface C. Egboka and Alex I. Opara. (2015). the Mechanics of Civil -Works Induced Gully Erosion: Applications to Development of Preventive Measures in South Eastern Nigeria. Applied Ecology and Environmental Sciences, Vol. 3, No. 2, pp. 60-65

[10] Igbokwe, et al. (2008): Mapping and Monitoring the Impact of Gully Erosion in Southeastern Nigeria with Satellite Remote Sensing and Spatial Information Science. In: Intl. Archives of Photog. Remote Sensing and Spatial Information Sciences.vol. 37, Part B, pp. 865-71, Beijing. China.

[11] Obidimma C. Ezezika and Olorunfemi Adetona. (2011). Resolving the gully erosion problem in Southeastern Nigeria: Innovation through public awareness and community. Journal of Soil Science and Environmental Management Vol. 2(10), pp. 286-29.

[12] Onu, N. N and Opara, A. I., (2012). Analysis and Characterization of Njaba River Gully Erosion, Southeastern Nigeria: Deductions from Surface Geophysical Data;Australian Journal of Basic and Applied Sciences, Vol. 6 Issue 4, pp122

[13] Okagbue, C.O and K.O. Uma (1987), performance of gully eroson control measures in south eastern Nigeria. Proceeding of the International Symposium on Forest Hydrology and Watershed Management, Vancouver, Canada. IAHS Publication, 167, pp 163-172.

[14] Reyment, R.A., (1965). Aspects of the geology of Nigeria. Ibadan, Nigeria: Ibadan University Press, 133

[15] Usman, et al. (2014) hydrogeological implications of environmental devastation in Orlu and its evirons South Eastern, Nigeria. Journal of Environment and Earth Science. Vol.4, No.23, pp 84-95. 